\title{
Challenges and Obstacles for Syrian Refugee Women in the Turkish Labor Market
}

\author{
Lamiha Ozturk *, Zehra Vildan Serin and Hamdiye Altınoz \\ Faculty of Social Sciences, Hasan Kalyoncu University, 27000 Gaziantep, Turkey \\ * Correspondence: lamiha.ozturk@hku.edu.tr
}

Received: 5 March 2019; Accepted: 19 June 2019; Published: 26 June 2019

check for updates

\begin{abstract}
The civil war in Syria resulted in the displacement of 5.7 million civilians between 2011 and 2018. Approximately four million of these civilians started to live in Turkey as refugees trying to integrate themselves into the labor market. The present research is a case study regarding the obstacles faced by Syrian refugee women's access to the labor market in Şanlıurfa, Turkey. To this end, a survey was carried out on a population of 341 migrants under a temporary protection regime comprising 207 women. The results obtained indicate numerous problems and show the needs of Syrian women. For example, Turkish language fluency and low education and skill levels are among the largest barriers for employment. Moreover, the opacity of bureaucratic procedures and non-computerized work permit applications are shown to be another slowing factor in this process. Compared with their home countries, Syrian women are more active in Turkey. However, a majority is involved in precarious and seasonal jobs. The problems of childcare and the feudal (male-dominated) nature of many homes deter Syrian women from contributing economically, and despite being a generally young population, most hold seasonal jobs, which leave little opportunity for career development. It is recommended that, to overcome structural barriers in accessing the labor market, Syrian refugee women need long-term training rather than restrictive policies.
\end{abstract}

Keywords: Syrian refugee women; labor market; integration; Turkey

\section{Introduction}

According to the Annual Global Trends statistical report published in June 2018 by the UNHCR (United Nations Refugee Agency) [1], 68.5 million people were uprooted in 2017. This report attests to the size of the population on the move, which stands at 44,500 individuals per day worldwide.

According to [2], "Refugees who have fled their countries to escape conflict and persecution account for 25.4 million of the 68.5 million uprooted people, an increase of 2.9 million from 2016 and also the largest increase ever registered by UNHCR for a single year". Armed conflict forces individuals to move involuntarily to other locations. This forced migration is discussed firstly in terms of the humanitarian emergency and later, in terms of security, education, and broader social issues.

Having ratified the 1951 Geneva Convention relating to the Status of Refugees, which limits "refugee status" to persons fleeing "events in Europe", Turkey cannot grant Syrian migrants refugee status. Since 2014, these migrants have had a special status-that is, temporary protection, which allows them access to public services, such as health and education. The consequence of the presence of refugees in any host country, especially on the labor market, is a recurring issue, as the arrival of new refugees in the workforce puts pressure on wages and working conditions.

With more than 3.5 million Syrians, Turkey is the country hosting the most refugees in the world [2]. Since 2014, these refugees have had temporary protection under the umbrella of the Ministry of Interior Directorate General of Migration Management. However, the camps opened under the auspices of the UNHCR only accommodate $9 \%$ of these refugees [2], with the remainder living outside and mostly in 
border cities, such as Şanlıurfa, Hatay, and Gaziantep. When one looks more closely at the profile of these refugees, $53 \%$ of them have proven precarious situations. Minors and women consist of $75 \%$ of all Syrian refugees in Turkey. In the absence of an official census carried out in detail by the authorities on the employment situation, the figures can only be estimated. Surveys carried out by the Disaster and Emergency Management Authority (AFAD) and the International Refugee Rights Association (IRRA) take the same co-location unit de facto, and some of the workers housed in their workplaces (domestic employees, agricultural laborers in particular) are, thus, exempt from these surveys, leading to biased figures. It is, therefore, with caution, and accepting a margin of error, that one must consider the figures available about Syrian refugees under temporary protection in Turkey. According to the Ministry of Interior's Directorate General of Migration Management, in December 2018, 47.6 per cent of Syrian refugees under temporary protection were children between the ages of 0 and 18 [3]. Also, according to other statistical reports by the same authority, 1,656,845 Syrian women were under temporary protection in Turkey. In many countries, refugees receive material assistance from UNHCR and are, thus, placed in a position of welfare assistance that does not encourage their professional integration into the labor market. For this reason, the Turkish government decided to put an end to this situation in 2014 by passing appropriate laws [4] (Law Number: 29153 on to temporary protection for Syrians). The aim was to help these refugees become economically independent and to contribute to the Turkish economy because refugees are not allowed to work without the explicit authorization of the authorities and must make a formal application to the Ministry of Family, Labor, and social Affairs. According to the statistics released by the stated ministry in 2018, only 27,930 work permits were issued to Syrians, which is quite modest in comparison with their 3,622,366 million population. It is important to note that only 41,343 temporarily protected refugees applied for a work permit. One may simply ask why more refugees do not apply. The application process calls for the work permit to be directly requested by the person concerned, and employers have no role at all. If the candidate has a work permit, it will be easier for employers to recruit them to possibly make a declaration to the authorities. The work permit application process is long and requires bureaucratic knowledge, and since refugees are foreign to the Turkish bureaucracy, they lack the information to take action. To minimize errors and facilitate the access of foreign migrants to the labor market, the employer should request a work permit directly from the authorities. Only Syrian migrants working in the agricultural sector are exempt from a work permit. Indeed, as in many neighboring countries to Syria, Syrian refugees do much work in the agricultural sector [5]. According to Akaya [6], women and children are the most significantly impacted victims of the refugee problem. With this in mind, the main purpose of this article is to analyze the challenges and limitations faced by Syrian refugee women under temporary protection in terms of their integration process into the labor market in Turkey, focusing on 469,085 Syrian refugees living in Şanlıurfa, which is a town close to the Syrian border and the second preferred Turkish city by Syrian refugees in Turkey. The city of Şanlıurfa, bordering Syria, with its ease of access, presence of relatives, and similarities in culture and language makes it the second most populated area, after Istanbul, by Syrian migrants present in Turkey. According to AFAD, 469,085 migrants under temporary protection have taken up residence in this city, making up a quarter of its total population. Such a high concentration is the main reason for choosing this city for our research. Our study aimed to better understand the degree of participation of these women in the labor market and the difficulties and barriers they experience in being part of the workforce.

\section{Literature Review}

There is an intensive academic literature related to participation in the labor market by refugee women who have had to leave their home countries because of internal conflicts. Their legal status [7], health issues, food aid or difficulties in obtaining decent accommodation are among the main research topics [8,9]. Other researchers [10-13] have focused on the economic and psychological impact of the presence of Syrians refugees on the population of the host country, financial assistance policies in their favor, and whether or not to subject them to taxation. Their legal status has also been indicated by many 
scholars as one of the major barriers against their employment. Akaya [14] focuses on the learning of the Turkish language by Syrian refugees. Health and psychological conditions have also been found to be a significant factor in entering the labor market in host countries. Loneliness and loss of confidence are shown to the main psychological factors among Syrian refugee women [15]. Bayraktar and Keskin [16] explored the impacts of the economic crisis of Syrian migrant on the accession process of Turkey to the EU. Cengis [17] examined the refuge crisis in Kilis, Turkey. According to the report of the Disaster and Emergency Management Authority (AFAD), in Syrian families, husbands tend to forbid their wives to get out of camps in winter and summer [18]. Yilmaz [19] investigated the Syrian refugee women in rural areas and revealed that women are more likely to leave their homes in rural areas. Yilmaz [18] mobilizes this behavioral change by integrating these women into the labor market and education, as well as the rural exodus of these women to an urban area in the host country. The most affected by the consequences of this involuntary migration are children and women. These uprooted women, who have limited social circles and lives in their home countries, end up with an even smaller social life.

Indeed, for these migrant women, their social lives are limited to visiting their entourage during days of religious festivals. Apart from these events, women do not leave their homes. Loneliness and loss of confidence are the main psychological effects related to the consequences of uprooting forced on these women and children [15]. These effects result in a partitioning of these women around their closest entourage, which is palpable in camps. Other consequences include keeping these women away from the labor market they were part of in their countries of origin, where, particularly in the agricultural sector, they were often quite active and productive.

According to the statistical report of AFAD, $87 \%$ of Syrian women in Turkey are unemployed. Of these, $56 \%$ are housewives, and about $30 \%$ have no professional training. AFAD [20] suggested in its report that the percentage of women who work is $7 \%$ among women aged 30 to 44 . Despite social assistance offered by the Turkish government, a significant number $(23.7 \%)$ of Syrian refugees under temporary protection live below the poverty line [21]. The integration of Syrian women with this status into the production process is, as such, crucial both for the economic independence of these families and the reduction of crime among refugees. Few studies have focused on the relationship between poverty and crime, and the outcomes are rather unclear [22]. Statistical reports state that unemployment among young people between 15 and 24 is very high [23]. Mostly Syrian women and children are often helpless and defenseless against crime and sexual discrimination [24-26]. Hence, public policies aimed at reducing the rate of unemployment and the precariousness of young Syrian refugees must favor integrating Syrian women into the labor market. To this end, the present work attempts to highlight such barriers for Syrian refugee women's participation in the labor market in order to reduce poverty and discrimination.

\section{Methodology}

\subsection{Participant Sample}

In order to identify and analyze the difficulties faced by Syrian women placed under temporary protection to integrate into the Turkish labor market, we recruited for our exploratory study Syrian migrants (women and men) under temporary protection in Şanlıurfa to answer 35 questions. The city of Şanliurfa was chosen because of its high concentration of Syrian migrants under temporary protection in comparison with its total population. Indeed, the 469,085 Syrian migrants present in Şanlıurfa represent a quarter of the population of Şanlıurfa. Istanbul is the city that hosts most Syrian migrants, but it was not considered in this research because those under temporary protection there represent only $3.7 \%$ of its total population of roughly 16 million. We used the probabilistic method for selecting the population of the sample. The sample chosen was a stratified sample. Although our analysis focuses on the obstacles and difficulties encountered by Syrian women in their integration into the 
Turkish labor market, it is also important to carry out this analysis with Syrian men who are also looking for a job in order to compare the differences between the two groups.

\subsection{Survey Instrument}

We designed a survey consisting of 35 questions with preset answer options. The questions were developed from surveys previously conducted for other countries, such as Canada or the United States. These include surveys by Brzoska and Abdul-Rida [27] and Blair and Schneeberg [28]. Their questions covered socio-demographic aspects and questions about living conditions, income level, level of education, level of knowledge of the Turkish language, difficulties encountered when looking for a job (bureaucracy, discrimination, other, etc.), socio-professional category, year of arrival in Turkey, etc. In order to test the viability, understanding, and clarity of the questions a sample of 10 migrant women, volunteers under temporary protection were interviewed first. This preliminary survey was extremely rewarding for us because it allowed us to refine our questions and highlight several difficulties related to the terms used, in addition to understanding the significance of accurate translation between Turkish and Arabic. The pilot test also made room for clarifying the target group's understanding of the purpose of this research in advance. The questionnaire was applied by a fully bilingual female Turkish-Arab interviewer, as it was only under such a condition that men would allow their wives to be approached. The questionnaire was answered in writing (hard copy). The final version of the survey was filled between March and June 2018 by 341 (207 women and 134 men) Syrian migrants under temporary protection, residing in the city of Şanlıurfa in Turkey. A total of 242 participants answered the questions orally, and it was the interviewer who completed the questionnaire for them. In total, 99 participants completed the questionnaire themselves, without any help or support from the interviewer.

\subsection{Data Analysis}

The collected data was analyzed using the SPSS 26.0 program for Windows. Frequency analysis was applied to the data. Correlation, crossover, and frequency methods are the main methods used in the multivariate descriptive analysis. The study received approval from the Hasan Kalyoncu University Ethics Committee and authorization and support from AFAD.

\section{Results}

The analysis of demographic data indicates that our sample of Syrian refugee women comprised a relatively young population, with $53.6 \%$ of the participants being between 15 and 29 years of age. Women made up $60.7 \%$ of the total sample, and among the 207 women, $51.5 \%$ were between 15 and 29 , and $41 \%$ were between 30 and 44 . In other words, $92 \%$ of all the women surveyed were of working age (Table 1).

Table 1. Participants' age profile (\%).

\begin{tabular}{ccc}
\hline Age & N & \% \\
\hline $15-19$ & 83 & 24.3 \\
$20-24$ & 60 & 17.6 \\
$25-29$ & 40 & 11.7 \\
$30-34$ & 34 & 9.9 \\
$35-39$ & 33 & 9.7 \\
$40-44$ & 23 & 6.7 \\
$45-49$ & 21 & 6.1 \\
$50-54$ & 19 & 5.6 \\
$55-59$ & 11 & 3.2 \\
$60+$ & 17 & 5.2 \\
Total & 341 & 100.0 \\
\hline
\end{tabular}

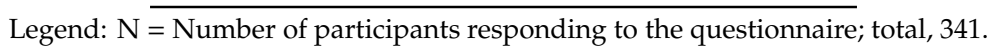


Marital status: In the entire sample, $47.4 \%$ were single, $45.2 \%$ were married, and $7.3 \%$ were either widowed or divorced. Of the 207 women, $61 \%$ were married, $18 \%$ were single, $5 \%$ were divorced, and $16 \%$ were widowed.

Literacy rate: Of the 207 Syrian women refugees surveyed, 19\% were illiterate.

Educational level: Of all the 341 Syrian refugees under temporary protection (men and women) surveyed, $18 \%$ said they had never been to school. Only $7 \%$ of this sample are currently attending school in Turkey. Of these 341 participants, 41.6\% were primary school graduates, 31.4\% were secondary school graduates, and $9.2 \%$ were higher-education graduates. The percentage of elementary school graduates among Syrian women under temporary protection in Şanliurfa is well above the sample average, with $43 \%$ reporting having attended primary school. Sixteen percent of these women completed secondary education. However, only 5\% received training in higher education. To the question "Have you taken any action to complete your studies since you settled in Turkey?", 23.4\% stated that their spouses or families would not allow for them to receive schooling. 17.3\% reported being unable to continue their studies because of their professional obligations, and 11\% declared that they do not attend school due to a lack of knowledge of the Turkish language.

Level of Turkish language (official language of the host country): $48.5 \%$ of the sample (341 participants) declared that they were able to speak and read in Turkish. Just over a quarter of the female population sample (27.6\%) reported having knowledge of Turkish and $70 \%$ claimed to be completely foreign to the Turkish language. When asked "What is the reason for you not taking a course in the Turkish language?", 36\% reported being unable to leave their young at home; 18\% said that learning Turkish will not be very helpful for their families; $15 \%$ claimed that the registration procedures are too complex for them; and $11.8 \%$ said that their husbands do not allow them to do so. When asked how they learned Turkish, 78\% of respondents said they learned from their entourage.

Level of knowledge of a foreign language (other than Turkish or Arabic): Of all the 341 interviewees, only $9 \%$ said they knew English enough to communicate orally and in written form. This figure is $16 \%$ for Kurdish. Of the 207 Syrian women surveyed, 4.5\% speak fluently in the Kurdish language. Once the demographic data were collected, the next step was to identify the needs and difficulties faced by the Syrian women in their job searches and, in particular, to analyze and compare the distribution of human resources, in other words, to compare the socio-professional status in their countries of origin and the host countries. As stated earlier, the target group is young, which is why it is not surprising to note that $25.5 \%$ of all male/female respondents were students in Syria. Further, $11.2 \%$ said that they had been traders in Syria before leaving, and 30\% had a profession. When looking at the sample figures for women, only $13.5 \%$ were employed back home. Of the women who migrated to Şanlıurfa, $31.9 \%$ were housewives. The results remain ambiguous because $26.6 \%$ of women and $20.3 \%$ of all participants did not wish to answer this question (Table 2). In comparison with their socio-professional activities in Turkey, the survey reveals that only $7 \%$ continued their studies in Turkey, $26.7 \%$ said they have no profession at the time of the survey, and $17.4 \%$ declared to be seasonal workers. Of all the women, almost half (45.9 per cent) declared to be housewives. Compared with their status in Syria, it appears that a number of women who previously worked or studied once they arrived in Turkey abandoned these activities. To the question "Why did you leave your activity or study?", $68 \%$ answered that their husbands or heads of family forbid all such engagements. For $48 \%$ of the women, childcare is the main handicap in their job search. To the question "Who contributes significantly to the household income?", 51.3\% of participants said that their children between the ages of 10 and 17 do so. Money earned by children is the main income of their home. Of the respondents, $22.1 \%$ said that it is the father who is the financial pillar of the house, and for $20.3 \%$, the woman (mother) takes this role. More than $96 \%$ of all the participants reported being a tenant at their place of residence. 
Table 2. Socio-professional activities in Syria.

\begin{tabular}{ccccc}
\hline Main Activity & $\mathbf{N}$ & $\mathbf{\%}$ & $\mathbf{n}$ & $\mathbf{\%}$ \\
\hline Student & 87 & 25.5 & 47 & 22.7 \\
Business & 38 & 11.2 & 8 & 3.9 \\
Housewife & 66 & 19.4 & 66 & 31.9 \\
Civil Servant & 14 & 4.2 & 2 & 0.9 \\
Private-Sector Employee & 20 & 5.8 & 9 & 4.3 \\
Other Professions (lawyer, doctor) & 4 & 1.1 & 0 & 0 \\
Unemployed & 17 & 5 & 11 & 5.4 \\
Farmer & 26 & 7.5 & 9 & 4.3 \\
No Response & 69 & 20.3 & 55 & 26.6 \\
Total & 341 & 100 & 207 & 100 \\
\hline
\end{tabular}

Legend: $\mathrm{N}=$ Number of participants answering the questionnaire; $341 \mathrm{n}$ : number of participant women.

To the question, "did you work last month?", $48.5 \%$ of participants responded positively. In terms of the length of the employment contract or simply the duration of work, $16.5 \%$ of respondents reported to rarely be working for more than a month in the same company, while $24 \%$ said they change companies every 3 months or so. About half of the respondents (48.1\%) did not wish to answer this question. When the participants were asked in which sector they work is, $18.8 \%$ stated they work in the agricultural sector, $12 \%$ in the industrial sector, and $29 \%$ in the service sector. The agricultural sector was the main place of employment (31\%) for the 207 women, and $11 \%$ worked regularly in the service sector.

When we inquired about their employment status, a majority of the total sample (54\%) reported to work illegally (without a work permit and/or not declaring taxes and social security). This figure was $74 \%$ for the sample made up of 207 women. See Table 3.

Table 3. Socio-professional activities in Turkey.

\begin{tabular}{ccccc}
\hline Main Activity & $\mathbf{N}$ & $\mathbf{\%}$ & $\mathbf{n}$ & $\mathbf{\%}$ \\
\hline Student & 24 & 7 & 11 & 5.3 \\
Business & 0 & 0 & 0 & 0 \\
Housewife & 95 & 27.8 & 95 & 45.9 \\
Civil Servant & 0 & 0 & 0 & 0 \\
Private-Sector Employee & 9 & 2.6 & 0 & 0 \\
Other Professions & 1 & 0.3 & 0 & 0 \\
Unemployed & 91 & 26.7 & 62 & 30 \\
Farmer & 9 & 2.6 & 0 & 0 \\
self-employed & 16 & 4.7 & 0 & 0 \\
No Response & 37 & 10.9 & 8 & 3.9 \\
Seasonal worker & 59 & 17.4 & 31 & 14.9 \\
Total & 341 & 100 & 207 & 100 \\
\hline
\end{tabular}

Legend: $N=$ Number of participants answering the questionnaire; 341, $n$ : number of participant women.

To the question "Why do you work illegally?", 68\% mentioned fear of cessation of aid payments from the respective authorities. For $29 \%$, it was not their personal choice, but a condition imposed by their employers. In terms of monthly income, 102 participants out of 341 (or 30\%) said they earn less than 1000 TL (approx. \$187), with 59\% unwilling to answer this question. Regarding the reasons for their difficulties in finding a job or integrating into the labor market, $12.3 \%$ said they cannot find jobs matching their human capital, and $12.8 \%$ reported being discredited during their professional interviews.

As for women, $21 \%$ reported that the language barrier was the main obstacle in their professional integration, and for $18 \%$, the main barrier was lacking work permits and bureaucratic difficulties to obtain work permits. The correlation between education level and employment status showed that 
when the level of education increases, so does the chances of entering the Turkish labor market. Indeed, $83.9 \%$ of the interviewees with a university degree had already been integrated as such. Conversely, when the schooling rate is low, the chances of landing a job decrease. According to the data collected, $44.7 \%$ of those who had not completed their schooling were in a precarious condition and could not join the workforce. Our findings suggest a correlation between employment status and knowledge of a foreign language and that the knowledge and practice of Turkish and/or the English language greatly enhances the chances of entering the labor market.

\section{Conclusions and Discussion}

Regulation No. 29153 [4] on the temporary protection of Syrians, published in the Official Gazette in October 2014, formally permits Syrian migrants to obtain a work permit. The regulations also allow these migrants to start their businesses with the help of micro-credits granted by the Turkish government. Despite this, a significant number of Syrian migrants under temporary protection continue to work illegally [29]. This is confirmed by our study, since almost all of the participants reported to work in the informal sector. Difficult access to information, the opacity of bureaucratic procedures, and the non-computerization of work permit applications are all reasons for the low integration of Syrian migrants into the labor market. Granting Syrian refugees a formal right of access to formal work in Turkey is a first step towards their economic integration, but many obstacles persist [30]. In detail, non-computerization is a real problem because refugees who apply for a work permit must submit their application to the Ministry of Family, Labor, and Social Services. This is especially difficult for refugee women, since they have to travel elsewhere to apply for a work permit. Computerization and the establishment of an electronic application platform will facilitate and increase the number of work permit applications, as well as limit the number of unregistered workers. Among the obstacles found in our study, the language barrier seems to be problematic for both men and women but much more problematic for women. Indeed, in comparison with their male counterparts, Syrian women under temporary protection who participated in the survey reported only basic knowledge of the Turkish language. The employability of these women was, hence, almost close to zero in sectors other than agriculture, thus preventing their professional development. It seems clear that priority must be given for Syrian migrants under temporary protection to learn the Turkish language, as this linguistic gap appears to be the common core for a variety of problems encountered by Syrians migrants. As the correlation appears to be positive between employability and knowledge of the language of the host country, it seems appropriate to set up language training facilities for this population. Local authorities encourage Syrian migrants to develop their language skills, but the government institutions recognized by the Ministry of Education and authorized to issue language certificates are limited. Our study suggests that not acquiring such linguistic competence has an automatic repercussion on the level of education. Of the Syrian women who participated in the study, more than half of them gave up their studies once they arrived in Turkey.

Adding to the stated obstacles are the family and professional obligations of young women. It appears that the feudal nature of many homes dissuades Syrian women from contributing economically to the home. Indeed, whether it is the pursuit of studies and/or professional integration, a majority of the women in our sample say they have abandoned all activities outside the family home because their heads of family oppose it. Among the barriers to their integration into the labor market, almost all of the women in our sample say they gave up working because of a lack of help and support for their children, who indeed occupy a dominant place in our analysis. One of the most concerning observations is that of children working illegally. It seems that children, especially children aged between 10 and 17, make a significant contribution to the household income since a majority of participants (men and women) admitted that the head of the household in terms of income are in fact these children. Once the child becomes a source of income indispensable for the household, it seems difficult to encourage parents to send them to school, instead. 
Another purpose of this study was to collect data on the types of skills and experiences of Syrians residing in Turkey. The results confirm those by Shariff et al. [31] regarding the profile of international migrant laborers, stating that the majority of women worked in the country of origin. Both male and female labors remained largely single. Kocaman [32] in his study points to the very low literacy rate of foreign migrants in Turkey. The education level of Syrian women in our sample is very low, too, and, as emphasized by Del Carpio et al. [30], these women are unlikely to become economically active with standard wage status in the private sector. These women are attached, for cultural and family reasons, to their homes, which implies that, perhaps, it would be appropriate to encourage work at home for these women and promote entrepreneurships. This would enable these women to become economically active and, thereby, integrate them into the formal labor market. The survey revealed that only $13.5 \%$ of the women in our sample worked in Syria before they arrived in Turkey. This figure increased slightly (15\%) once the women resettled in Turkey, as the economic difficulties encouraged some in our sample to enter the workforce. However, the type of employment was precarious and of a seasonal nature, with many jobs being in the agricultural sector due the exemption of work permits for such jobs (as we stated earlier). In their work, Şen and Vural [33] also highlight the low rate of participation of Syrian women in working life in Turkey.

In summary, it seems that Syrian women in Turkey who participated in our survey had a low level of academic training, which, combined with their lack of knowledge of the Turkish language, formed an obstacle for their integration into the Turkish labor market. The authors suspect that the education factor is the cause for these women to be mainly employed in the agriculture sector, one which requires cheap labor without a diploma or prerequisite skills. On the other hand, Syrian women who have professional training, or can speak Turkish, integrated more easily and quickly into the Turkish labor market.

Beyond this literature overview, the main contribution of the paper is a detailed analysis of the link between the level of knowledge of the Turkish language and the ability of the Syrian women living in the Şanllurfa region to integrate into the labor market. As such, state authorities should encourage and facilitate the learning of Turkish for these women. However, these two factors are not the only obstacles; indeed, the analysis shows that husbands do not want their wives to enter the labor market to begin with, and family obligations are the main reason for this unwanted integration. In this regard, the authorities could conduct a more thorough sociological analysis to understand the contributing factors. Apart from this, the allowance and other aids offered to Syrian migrants under temporary protection seem to be a barrier to their professional integration into the workforce. In fact, participants reported they work unofficially for fear of losing these monetary aids. In order to ensure a decent standard of living for Syrian migrants, it seems difficult at present to put an end to the social welfare program. However, for integration, it would be advisable to continue to pay these financial aids for a certain period to those who declare being active as registered workers. Lastly, the impossibility for Syrian migrants to prove their skills and/or educational level by official documents slows down integration efforts. In the urgency of their departure, many Syrian migrants did not bring along with them their diplomas and other documents. Hence, to optimize and use human resources efficiently, the Council of Higher Education (YÖK) could set up a system of recognition of acquired experience and a diploma equivalency exam for migrant Syrians under temporary protection, as such recognition could encourage and increase the rate of formal work permits and, thus, encourage Syrian migrants to enter the labor market. Obviously, the present paper is not free of limitations. To begin with, it only focused on the city of Şanlıurfa, and, to further generalize the results, it will be important to conduct this same study in all the big cities hosting Syrian refugees-in this case, in Turkey. The second limit lies in the choice of the sample, as the respondents were selected randomly and do not represent the total population of this region. Finally, it will be interesting to devise purely sociological questions in order to understand the reasons that dissuade Syrian women from working and educating themselves. 
Author Contributions: L.Ö. for conceptualization, methodology, formal analysis, writing-original draft preparation and writing-review and editing. Z.V.S. for valisation, data curation, project administration and supervision. H.A. for software and investigation.

Funding: This research received no external funding.

Acknowledgments: We would like to thank the Syrian participants who accepted to answer our questions for their sincerity and welcome.

Conflicts of Interest: The authors declare no conflict of interest.

\section{References}

1. UNHCR. Global Trends Forced Displacement in 2017. 2018. Available online: https://www.unhcr.org/ globaltrends2017/ (accessed on 19 June 2019).

2. UNHCR. The Educational External Update; Turkey. 2017. Available online: https://data2.unhcr.org/en/ documents/download/57330 (accessed on 25 June 2019).

3. Ministry of the Interior Directorate General of Migration Management. Yillara gore geçici koruma kapsamındaki Suriyeliler; GAM Publisher: Ankara, Turkey, 2018.

4. Resmi Gazete, Regulation Number 29153. 2014. Available online: http:/www.resmigazete.gov.tr/eskiler/ 2014/10/20141022.htm (accessed on 25 June 2019).

5. Akpınar, T. Türkiye'deki Suriyeli Mülteci Çocukların ve Kadınların Sosyal Politika Bağlamında Yaşadıkları Sorunlar. Balkan ve Yakın Doğu Sosyal Bilimler Dergisi 2017, 3, 16-29.

6. Yaşar, R. Kilis'te Sığınmacı Algısı Toplumsal Otizm ve Ötekileştirmenin İlk Görünümleri. 2014. Available online: https://play.google.com/store/books/details/Kilis_te_S\%C4\%B1\%C4\%9F\%C4\%B1nmac\%C4\%B1_ Alg\%C4\%B1s\%C4\%B1_Toplumsal_Otizm_ve_\%C3\%96teki?id=9yhwBQAAQBAJ\&hl=en_US (accessed on 19 June 2019).

7. Uzun, A. Günümüzün Sosyal ve Ekonomik Sorunu Olan Suriyelilerin Mülteci ve Ekonomi Hukuku Bakımından Değerlendirilmesi. Ankara barosu dergisi 2015, 1, 105-120.

8. ORSAM Rapor No: 189. Hazırlayan: Oytun Orhan, Proje Koordinatörü, Orsam (Ortadoğu Stratejik Araştırmalar Merkezi); ORSAM: Ankara, Turkey, 2014.

9. ORSAM. Suriyeli Sı̆̆ınmacıların Türkiye'ye Etkileri; ORSAM: Ankara, Turkey, 2015.

10. Dinçer, O.B.; Federici, V.; Ferris, E.; Karaca, S.; Kirişçi, K.; Çarmıklı, E.Ö. Suriyeli Mülteciler Krizi Ve Türkiye/Sonu Gelmeyen Misafirlik; Brookings Enstitüsü ve Uluslararası Stratejik Araştırmalar Kurumu (USAK): Ankara, Turkey, 2013.

11. Mülteci Ölümleri Raporu; Imkander Yayını: 2014. Available online: https://www.imkander.org.tr/resim/file/ 2016/imkander-2016-rapor-renkli.pdf (accessed on 25 June 2019).

12. Tunç, A.Ş. Mülteci Davranışı ve Toplumsal Etkileri: Türkiye'deki Suriyelilere İlişkin Bir Değerlendirme. 2015. Available online: https://dergipark.org.tr/tesamakademi/issue/12946/156434 (accessed on 16 June 2019).

13. Siverekli, E.; Ertuğrul, H.G. Misafirlikten Diasporaya Doğru Suriyeli Sığınmacıların Vergi Algısı Üzerindeki Etkisine Yönelik Bir İnceleme. Çanakkale Onsekiz Mart Üniversitesi Biga İktisadi ve İdari Bilimler Fakültesi. Yönetim Bilimleri Dergisi 2016, 14, 491518, (Yayın No: 2586575).

14. Akay, E. Kapitalizm'in Son Oyunu. Algı Yönetimi. Köklü Değişim Dergisi 2014, 117-120.

15. Yılmaz, T.T. Göç'ün Kadın Yaşamı Üzerindeki Etkileri, Yüzüncü Yıl Üniversitesi Sosyal Bilimler Enstitüsü. Yayınlanmamış Yüksek Lisans Tezi Van; Yüzüncü Yıl Üniversitesi Sosyal Bilimler Enstitüsü: Van, Turkey, 2005.

16. Bayraktar, B. Suriyeli Dom Göçmenler, Suriyeli Dom Göçmen Mevcut Durum Araştırması; Altan Matbaası: Ankara, Turkey, 2016.

17. Cengiz, D. Zorunlu Göçün Mekânsal Etkileri ve Yerel Halkın Algısı: Kilis Örneği; Turkish Studies International Periodical for the Languages, Literature and History of Turkish or Turkic: Ankara, Turkey, 2015; p. 10.

18. Afet ve Acil Durum Yönetimi Başkanlığı, (AFAD). Türkiye'deki Suriyeli Kadınlar; AFAD: Ankara, Turkey, 2014.

19. Yılmaz, A. Göç Sürecinde Kadın: Aile İçi Konumu Üzerine Bir Araştırma; Adnan Menderes Üniversitesi Sosyal Bilimler Enstitüsü, Yayınlanmamış Yüksek Lisans Tezi: Aydın, Turkey, 2008.

20. Afet ve Acil Durum Yönetimi Başkanlığı, (AFAD). Afet Raporu: Suriye, Dünyanın En Cömert Ve En Çok Sığınmacıya Ev Sahipliği Yapan Ülkesi: Türkiye. 2016. Available online: https://www.afad.gov.tr/tr/2373 (accessed on 22 December 2016). 
21. World Bank/WFP. Pre-Assessment Baseline Results. 2017. Available online: https://docs.wfp.org/api/ documents/WFP-0000039740/ (accessed on 25 June 2019).

22. Cusson, M. Les relations paradoxales entre la pauvreté et la délinquance. 2008. Available online: http://classiques.uqac.ca/contemporains/cusson_maurice/relations_paradoxales_pauvrete_delinquance/ relations_paradoxales.html (accessed on 16 June 2019).

23. Fougere, D.; Kramarz, F.; Pouget, J. L'analyse économétrique de la délinquance. Une synthèse de résultats récents. Revue française d'économie 2005, 19, 3-55. [CrossRef]

24. Freedman, J. Sexual and gender-based violence against refugee women: A hidden aspect of the refugee "crisis". Reprod. Health Matters 2016, 24, 18-26. [CrossRef] [PubMed]

25. UN Women. Report of the Legal Rights of Women and Girl Asylum Seekers in the European Union; Europe and Central Asia Regional Office: Istanbul, Turkey, 2017.

26. Mazlumder Woman Studies Group. The Report on Syrian Woman Refugees Living Out of the Camps; Mazlumder: Istanbul, Turkey, 2014.

27. Brzoska, P.; et Abdul-Rida, C. Participation in cancer screening among female migrants and non-migrants in Germany: A cross-sectional study on the role of demographic and socioeconomic factors. 2016. Available online: https://www.ncbi.nlm.nih.gov/pmc/articles/PMC5265834/ (accessed on 16 June 2019).

28. Blair, A.H.; et Schneeberg, A. Changes in the 'healthy migrant effect' in Canada: Are recent immigrants healthier than they were a decade ago? J. Immigr. Minority Health 2014, 16, 136-142. [CrossRef] [PubMed]

29. Paksoy, H.M.; Koçarslan, H.; Kılınç, E.; Tunç, A. Suriyelilerin Ekonomik Etkisi: Kilis İli Örneği. Birey ve Toplum Sosyal Bilimler Dergisi 2015, 5, 143-173. [CrossRef]

30. Del Carpio, X.; Seker, D.S.; Yener, L.A. L'intégration des réfugiés au marché turc du travail. 2018. Available online: https://www.fmreview.org/fr/economies/delcarpio-seker-yener (accessed on 25 June 2019).

31. Sharrif, M.N.; Mohd Nor, N.A.; Abidin, A.Z. Profiling international migrant labours by socio-demographic characteristics and motivational factors: The case of tourism and hospitality industry. Int. J. Adv. Appl. Sci. 2017, 4, 61-67. [CrossRef]

32. Kocaman, S. Kentsel Alanlara Göç Eden Kırsal Nüfusun Kentsel Uyumu Ve Kentlileşme Düzeyi Üzerine Uygulamalı Bir Araştırma: Ağrı Örneği. J. Int. Soc. Res. 2014, 7, 335-349.

33. Şen, A.B.; Vural, C. Suriye Iç Savaşında Göç ve Kadın. Yaratıcı Drama Dergisi 2014, 9, $29-40$.

(C) 2019 by the authors. Licensee MDPI, Basel, Switzerland. This article is an open access article distributed under the terms and conditions of the Creative Commons Attribution (CC BY) license (http://creativecommons.org/licenses/by/4.0/). 